\title{
Seasonal variation in parasite occurrence and microhabitat distribution of monogenean parasites of gudgeon Gobio gobio (L.)
}

\author{
R. BLAŽEK ${ }^{1 *}$, J. JARKOVSKÝ ${ }^{2}$, B. KOUBKOVÁ ${ }^{1}$, M. GELNAR $^{1}$
}

\begin{abstract}
${ }^{1}$ Department of Botany and Zoology, Faculty of Science, Masaryk University, Kotlářská 2, 611 37, Brno, Czech Republic, E-mail: demon@sci.muni.cz; ${ }^{2}$ Centre of Biostatistics and Analyses, Faculty of Medicine and Faculty of Science, Masaryk University, Kamenice 126/3, 62500 Brno, Czech Republic
\end{abstract}

\begin{abstract}
Summary
Seasonal changes in occurrence, infracommunity composition and microhabitat distribution of the monogenean parasites of gudgeon Gobio gobio (L.) were studied during two years in the River Haná (Czech Republic). Altogether 212 specimens of gudgeon were examined and a total of 6456 specimens of eight monogenean species were recorded: Dactylogyrus cryptomeres, Gyrodactylus gobiensis, Gyrodactylus gobii, Gyrodactylus gasterostei, Gyrodactylus vimbi, Gyrodactylus markakulensis, Gyrodactylus sedelnikowi and Paradiplozoon homoion. The occurrence of monogeneans correlated with seasonal changes of water temperature. In 2001, gyrodactylids peaked in March and D. cryptomeres in May, whereas in 2002, gyrodactylids peaked in May and D. cryptomeres in July. The majority of specimens of all Gyrodactylus species were found on the fins; the remaining specimens of Gyrodactylus were located on the body surface and gills, and all Dactylogyrus and Paradiplozoon specimens were located on the gills. The microhabitat distribution of the monogeneans changed in relation to changing water temperature and intensity of infection.
\end{abstract}

Key words: Gobio gobio (L.), monogeneans, population dynamics

\section{Introduction}

Monogeneans are common members of fish parasite communities in freshwater and marine habitats. Most monogenean species are host-specific; others can infect several hosts from different families (Poulin, 1992). Dactylogyrus and Paradiplozoon species are oviparous and parasitize fish gills. Gyrodactylids are viviparous and parasitize mainly the fins, gills and the body surface. New-born worms are fully grown and attach themselves directly to

\footnotetext{
${ }^{*}$ corresponding author
}

the host alongside their parent and transmission becomes through host-to-host contact, including contact with dead fishes, and by reattachment of previously detached parasites (Bakke et al., 1992). This process together with the unique mode of reproduction allows a rapid increase of the population size in a relatively short period, which can have a significant negative effect on a condition and survival of fish (Bakke et al., 1992).

Variation in monogenean population size is mainly explained by seasonal changes in water temperature (Kamiso \& Olson, 1986; Cone \& Cusack, 1988; Valtonen et al., 1990; Barse, 1998). Temperature directly affects Gyrodactylus reproduction and survival time (Jansen \& Bakke, 1991), parasite behaviour, host behaviour, host density and host responses to infection (Bakke et al., 1992; Aaltonen et al., 1994; Andersen \& Buchmann, 1998; Bakke et al., 2007).

Microhabitat preference of monogenean parasites on host individuals has been investigated by many authors (e.g. Žitňan \& Hanzelová, 1982; Jensen \& Johnsen, 1991; Appleby, 1996; Mo, 1997). Gyrodactylids were found to be localized on different parts of the fish body depending on the phase of infection and developing host immune response (Harris, 1988; Buchmann \& Bresciani, 1998; Lindenstrøm \& Buchmann, 2000). Microhabitat preference might be also associated with changes in the intensity of infection (Jensen \& Johnsen, 1991).

Gudgeon Gobio gobio (L.) is a benthopelagic cyprinid fish common throughout Europe. Component communities of parasites of gudgeon have been studied by Dorovskikh (2005) in Russia and there have been several studies on gudgeon monogeneans in the Czech Republic (Ergens, 1991; Gelnar, 1991; Pečínková et al., 2005); however there is no study focusing on seasonality of gudgeon monogeneans and their microhabitat distribution. Consequently we examined seasonal changes in intensity of infection and prevalence of monogenean species parasitizing gudgeon. 
In particular, infracommunity structure and microhabitat preference of parasites were investigated with respect to changing water temperature and intensity of infection.

\section{Materials and Methods}

Gudgeon were caught in the River Haná in southeastern Moravia, Czech Republic ( $\left.49^{\circ} 16^{\prime} \mathrm{N}, 16^{\circ} 59^{\prime} \mathrm{E}\right)$. Mean width of the River Haná in the study area was $5 \mathrm{~m}$, mean depth was $25 \mathrm{~cm}$ and the rate of flow varied from 0.2 to $0.5 \mathrm{~m} . \mathrm{s}^{-1}$. Each month during 2001 and 2002, a sample of 10 gudgeon was collected by electrofishing and water temperature was measured to the nearest $0.1{ }^{\circ} \mathrm{C}$. Fish were transferred to the laboratory, kept individually in buckets and examined within 3 days for presence of metazoan parasites. Fish were killed by cutting the spine, measured to the nearest $0.1 \mathrm{~cm}$ and sex was determined. Altogether 106 specimens in $2001\left(L_{\mathrm{S}}\right.$, mean $\left.\pm \mathrm{SD}, 92.5 \pm 15.7 \mathrm{~mm}\right)$ and 106 specimens in $2002(116.0 \pm 12.9 \mathrm{~mm})$ were dissected. Microhabitat distribution of all parasites was recorded and all monogenean parasites were fixed in glycerine ammonium picrate (Malmberg, 1970) and later identified according to Gussev (1985).

The epidemiological terms such as prevalence, intensity of infection and dominance follow Bush et al. (1997). To determine the diversity of the infracommunity of each host fish Brillouin's index was calculated (Pielou, 1975). Fin area was determined using 20 specimens of gudgeon $\left(L_{\mathrm{S}} \pm\right.$ $\mathrm{SD}, 104.0 \pm 2.1 \mathrm{~mm})$. The density of gyrodactylids was obtained by dividing the number of parasites on each fin by the mean area of respective fin. Maximum density of gyrodactylids was evaluated from the fish on which the highest intensity of infection was observed and was calculated as one specimen of Gyrodactylus spp. per $5 \mathrm{~mm}^{2}$ on the pectoral fin of gudgeon in May 2001. Fish were separated into four groups according to temperature $(0-4.9,5$ $-9.9,10-14.9$ and $15-20.5{ }^{\circ} \mathrm{C}$ ) and into three groups according to intensity of infection $(1-20,21-50$ and 51 - 100 parasites) to study the relationship between temperature, intensity of infection and microhabitat distribution of the monogeneans.

Statistical analyses were carried out with Statistica for Windows 7.1 (StatSoft, 2006). Quantitative data on intensity of infection were $(\log +1)$ transformed prior to analysis. A Student $t$ test was used to test for differences in monogenean intensities of infection between studied years and between male and female fish. The Spearman rank order correlation was used to measure the relationship between the intensity and prevalence of parasites and fish standard length, and the relationship between the intensities of monogenean species and water temperature. A $\chi^{2}$ test was used to examine differences in prevalence of monogeneans and a Mann-Whitney $U$ test tested the difference in infracommunity species richness between years studied. The differences in Brillouin's diversity index among sampling months were determined by One-way ANOVA. Differences in microhabitat distribution in relation to temperature and intensity of infection were evaluated by Friedman ANOVA.

\section{Results}

As many as 212 specimens of gudgeon were investigated for the presence of metazoan parasites. Altogether 3914 and 2542 monogenean parasites of eight species were found in 2001 and 2002, respectively. The highest intensities of infection were observed in Dactylogyrus cryptomeres (Bychowsky, 1934), Gyrodactylus gobiensis

Table 1. Monogenean species and their prevalence, mean intensity of infection, maximum intensity of infection with indication of month and dominance in gudgeon (Gobio gobio) in 2001 and 2002.

\begin{tabular}{|c|c|c|c|c|c|c|c|c|}
\hline \multirow{3}{*}{ Species } & & & \multicolumn{6}{|c|}{$\underline{\text { Max }}$} \\
\hline & \multicolumn{2}{|c|}{ Prevalence (\%) } & \multicolumn{2}{|c|}{$\underline{\text { Mean intensity } \pm \mathrm{SD}}$} & \multicolumn{2}{|c|}{ intensity/month } & \multicolumn{2}{|c|}{ Dominance $(\%)$} \\
\hline & 2001 & 2002 & 2001 & 2002 & 2001 & 2002 & 2001 & 2002 \\
\hline D. cryptomeres & 47.2 & 68.9 & $11.25 \pm 22.07$ & $11.45 \pm 28.29$ & $84 / \mathrm{VI}$ & 172/VII & 31.1 & 48.7 \\
\hline G. gobiensis & 82.1 & 73.6 & $12.36 \pm 17.15$ & $6.58 \pm 11.42$ & $100 / \mathrm{V}$ & $82 / \mathrm{V}$ & 33.1 & 27.1 \\
\hline G. gobii & 71.7 & 50.0 & $9.80 \pm 13.09$ & $4.30 \pm 9.83$ & $53 / \mathrm{IV}$ & $70 / \mathrm{V}$ & 26.6 & 18.0 \\
\hline G. markakulensis & 23.6 & 18.9 & $0.52 \pm 1.35$ & $0.25 \pm 0.73$ & 8/VIII & 3/VIII & 1.4 & 1.1 \\
\hline G. gasterostei & 46.2 & 37.7 & $1.69 \pm 3.04$ & $0.89 \pm 1.59$ & $16 / \mathrm{V}$ & $9 / \mathrm{V}$ & 4.7 & 3.7 \\
\hline G. vimbi & 34.0 & 16.0 & $1.11 \pm 2.45$ & $0.27 \pm 0.66$ & $14 / \mathrm{IV}$ & $5 / \mathrm{V}$ & 3.0 & 1.1 \\
\hline G. sedelnikowi & 0 & 2.0 & 0 & $0.02 \pm 0.13$ & 0 & $1 / \mathrm{IV}$ & 0 & 0.1 \\
\hline P. homoion & 2.0 & 4.7 & $0.02 \pm 0.14$ & $0.06 \pm 0.27$ & $1 / \mathrm{XII}$ & 2/VII & 0.1 & 0.2 \\
\hline
\end{tabular}


(Glaser, 1974) and Gyrodactylus gobii (Schulman, 1953). Other species observed were Gyrodactylus markakulensis (Gvosdev, 1950), Gyrodactylus vimbi (Schulman, 1954), Gyrodactylus gasterostei (Glaser, 1974), Paradiplozoon homoion (Bychowsky \& Nagibina, 1959) and Gyrodactylus sedelnikowi (Gvozdev, 1950) (Table 1). Occasionally, metacercariae of the following three trematode species were observed: Tylodelphis clavata (Nordmann, 1832) (prevalence $5 \%$ ) in the eyes and Rhipidocotyle illense (Ziegler, 1883) (2\%) and Rossicotrema donicum (Skrjabin \& Lindtrop, 1919) $(0.4 \%)$ in the fin tissue. Fish were significantly larger in 2002 as compared to 2001 (Student $t$ test, $\mathrm{t}=-11.89, \mathrm{df}=210, P<0.01)$. In 2001 no relationship between fish standard length and parasite intensity was observed (Spearman correlation, $\mathrm{r}_{\mathrm{s}}=-0.121, P>0.05$ ), whereas in 2002 host length negatively correlated with parasite intensity (Spearman correlation, $\mathrm{r}_{\mathrm{s}}=-0.199, P<$ 0.05). D. cryptomeres and $G$. gobii infected female gudgeon more frequently in 2001 (Student $\mathrm{t}$ test, both $\mathrm{t}>2.65$, $\mathrm{df}=$ $91, P<0.01)$ whereas males were more frequently infected in 2002 (Student $\mathrm{t}$ test, both $\mathrm{t}<-2.65, \mathrm{df}=100, P<0.01$ ).

Dactylogyrus cryptomeres specimens represented almost half of all monogenean specimens collected in 2002 (Table 1 ). The maximum number of $D$. cryptomeres on a single fish was 172 specimens (July 2002). For Gyrodactylus spp., the highest intensity of infection was observed for $G$. gobiensis with 100 specimens (May 2001) (Table 1). Significantly higher mean intensity of infection in 2001 as compared to 2002 was observed for G. gobiensis, G. gobii, G. gasterostei and G. vimbi (Student t test, all $\mathrm{t}>2.16$, $\mathrm{df}=$ $210, \mathrm{P}<0.05)$. However, prevalences of $G$. gobii and $G$. vimbi only were higher in $2001\left(\chi^{2}\right.$ test, both $\left.P<0.01\right)$ (see Table 1). In contrast, D. cryptomeres was observed in similar intensities in both studied years (Student $\mathrm{t}$ test, $\mathrm{t}=$ 0.65 , $\mathrm{df}=210, P=0.516$ ) but the prevalence was higher in $2002\left(\chi^{2}\right.$ test, $\left.\mathrm{P}<0.01\right)$. Prevalence and mean intensity of $G$. markakulensis and $P$. homoion remained low in both years (Table 1).

There was a significant difference in monogenean infracommunity species richness between years. The most

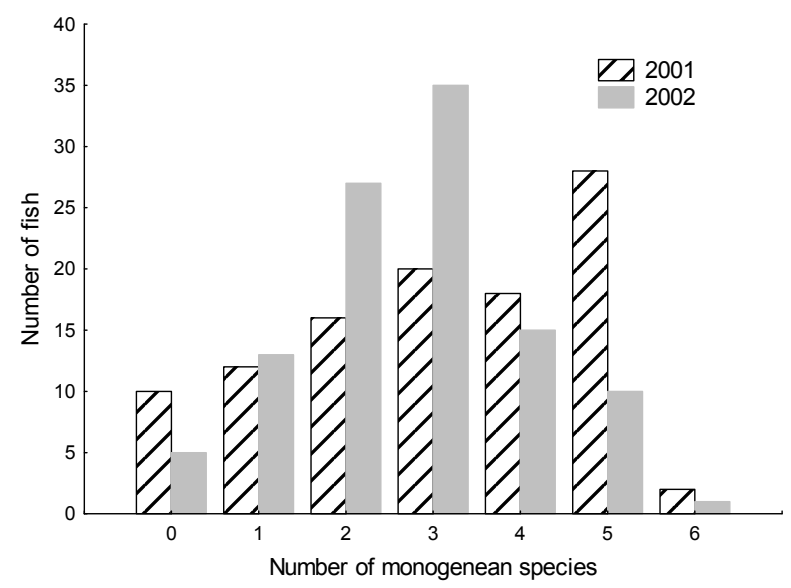

Fig. 1. Characteristics of monogenean infracommunities of gudgeon (Gobio gobio) in 2001 and 2002. common infracommunity consisted of five species in 2001 and three species in 2002 (Mann Whitney U test, $\mathrm{z}=$ $1.982, P=0.047$ ) (Fig. 1). The highest values of Brillouin's diversity index of the monogenean infracommunity were recorded in both years during the spring months. Months were grouped in accordance with significant simi-

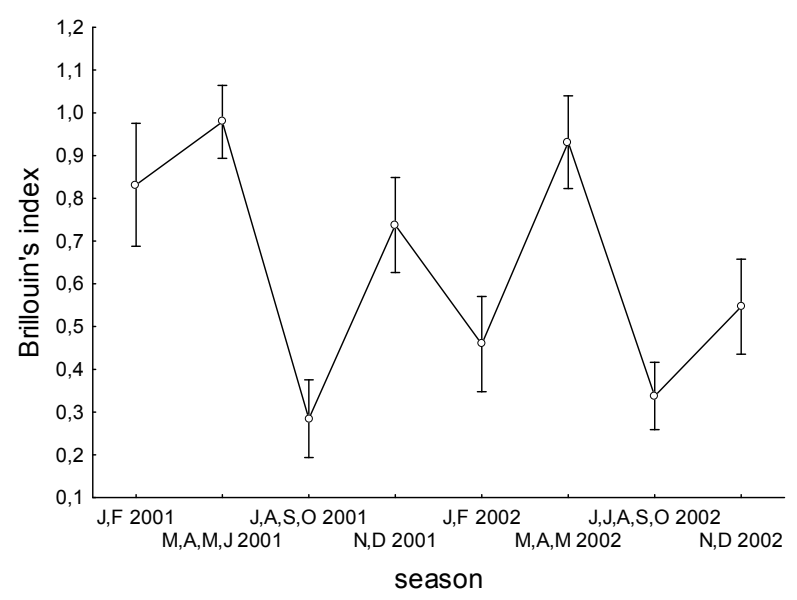

Fig. 2. Seasonal changes in Brillouin's index of monogenean infracommunities of gudgeon in 2001 and 2002. Months are grouped by seasons and similarity of Brillouin's index.

larities in Brillouin's index (Post-hoc tests of One-way ANOVA, $P<0.05$ ) (Fig. 2).

Prevalence of all monogenean species correlated with mean intensity of infection (Spearman correlation, all $\mathrm{r}_{\mathrm{s}}>$ $0.830, P<0.05)$. The intensity of gyrodactylids increased in spring with an increase of temperature above $6{ }^{\circ} \mathrm{C}$ (March 2001 and May 2002). During the summer months, intensity of gyrodactylids declined and started to increase again with falling temperature during the autumn and winter months. Amongst the gyrodactylids, only $G$. markakulensis was found more commonly during summer than in other months (Fig. 3A). Moreover, the occurrence of $G$. markakulensis was negatively correlated with the occurrence of G. gobiensis and G. gobii (Spearman correlation, both $\left.\mathrm{r}_{\mathrm{s}}<-0.150, P<0.05\right)$. The intensities of $D$. cryptomeres and $G$. markakulensis positively correlated with the water temperature (Spearman correlation, both $\mathrm{r}_{\mathrm{s}}$ $>0.187, P<0.05$ ), whereas the relationships of the water temperature and the intensities of G. gobiensis, G. gobii and G. gasterostei were negative (Spearman correlation, both $\mathrm{r}_{\mathrm{s}}<-0.285, P<0.05$ ), (Fig. 3A-C). The intensity of $D$. cryptomeres peaked when the water temperature increased above $14{ }^{\circ} \mathrm{C}$ during both years of study (May and June 2001 and July 2002) (Fig. 3C).

Dactylogyrus cryptomeres and $P$. homoion were strictly found on the gills (Fig. 4). Gyrodactylids were found primarily on the fins $(88.7 \%)$, but also on the skin $(8.9 \%)$, gills $(2.4 \%)$ and rarely on the barbels $(0.1 \%)$. In comparison with other gyrodactylids, G. gasterostei and G. vimbi were found more often on the skin (more than 20\%). More than $26 \%$ of $G$. markakulensis were observed on the gills, whereas less than $3 \%$ of the other gyrodactylids were 

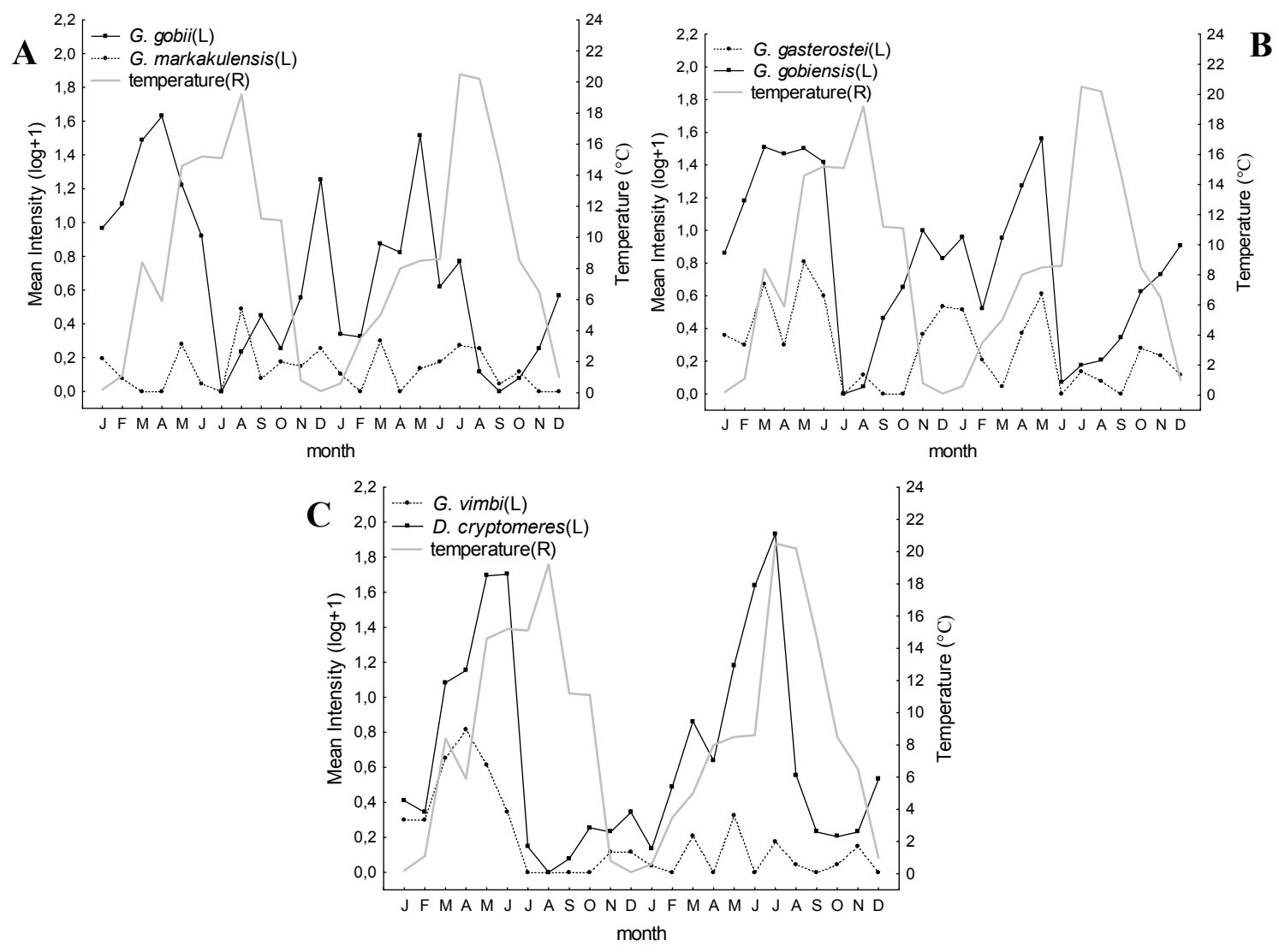

Fig. 3. Seasonal changes in the mean intensity of infection of monogenean species in gudgeon during 2001 and 2002. A) Gyrodactylus gobii and G. markakulensis; B) G. gasterostei and G. gobiensis; C) G. vimbi and Dactylogyrus cryptomeres.

found attached to the gills (Fig. 4).

Dactylogyrus cryptomeres preferred the first gill arch in warm months and the second and third gill arches in cooler months (ANOVA $\left.\chi^{2}(\mathrm{~N}=4, \mathrm{df}=3)=9.300, P=0.026\right)$ and was more often attached to the third gill arch when the intensity of infection was high (ANOVA $\chi^{2}(\mathrm{~N}=4, \mathrm{df}=2)$ $=6.500, P=0.039$ ) (Fig. 5A). Most Gyrodactylus individuals were observed on the pectoral and pelvic fins and

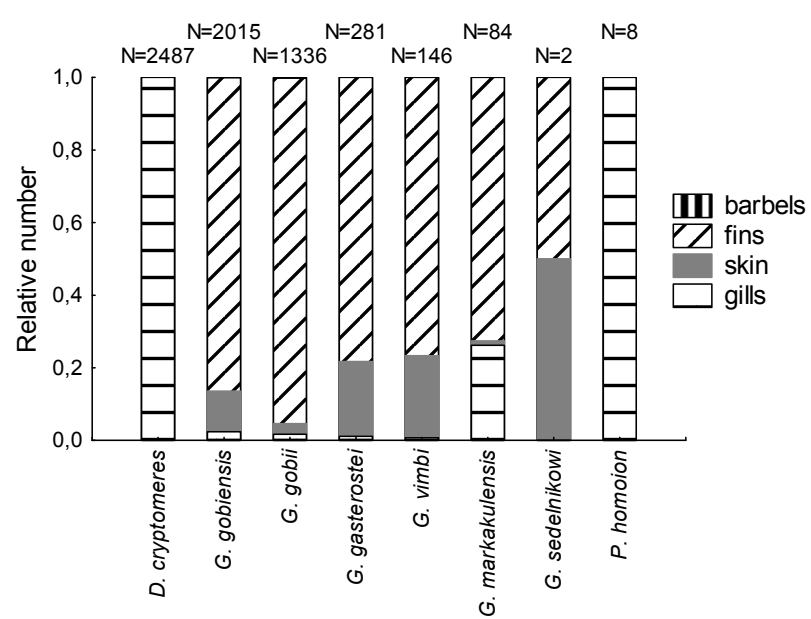

Fig. 4. The microhabitat of monogenean species. on gills, fins, skin and barbels of gudgeon. The number of individuals of species $(\mathrm{N})$ is indicated above the bars.
G. gobiensis also on the dorsal fin. Gyrodactylus markakulensis was found mainly on the gills (86\%) in cold months whereas in warm months $94 \%$ of the specimens were attached to the fins. Gyrodactylus gobiensis and $G$. gobii frequently parasitized pectoral and pelvic fins but their numbers increased on the skin in warm months $\left(\right.$ ANOVA $\chi^{2}(\mathrm{~N}=8$, df $=3)>8.846, P<0.04$ for both species). At higher intensity, the latter Gyrodactylus species were attached more frequently to pectoral fins and $G$. gobii also to pelvic fins (ANOVA $\chi^{2}(\mathrm{~N}=8$, df $=2)>$ $11.290, P<0.005$ for both species) (Fig. 5B, C).

\section{Discussion}

In the present study, eight monogenean species were observed on gudgeon. Four species (D. cryptomeres, G. gobiensis, G. gobii and G. markakulensis) were reported only from gudgeon and are considered as strict specialists (Harris et al., 2004). Three species (G. gasterostei, G. vimbi and $P$. homoion) are generalists. Gyrodactylus sedelnikowi is reported as a specific parasite for stone loach Barbatula barbatula (L.) (see Harris et al., 2004) and its finding in gudgeon is accidental. Stone loach was abundant at the sampling locality and during a growth and dispersal of gyrodactylids, they may also have transferred to the nonspecific gudgeon host (Poulin, 1992).

Population dynamics of monogeneans is influenced by water temperature, which directly affects reproduction and 
A

Dactylogyrus cryptomeres

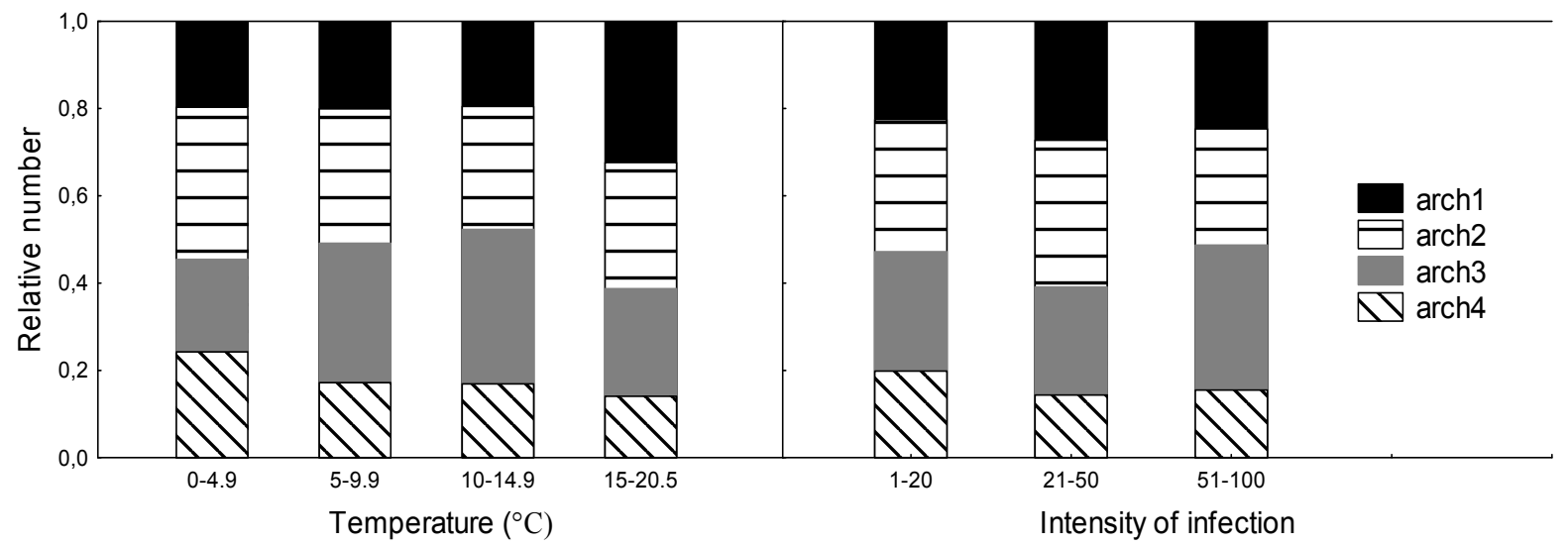

B

Gyrodactylus gobiensis

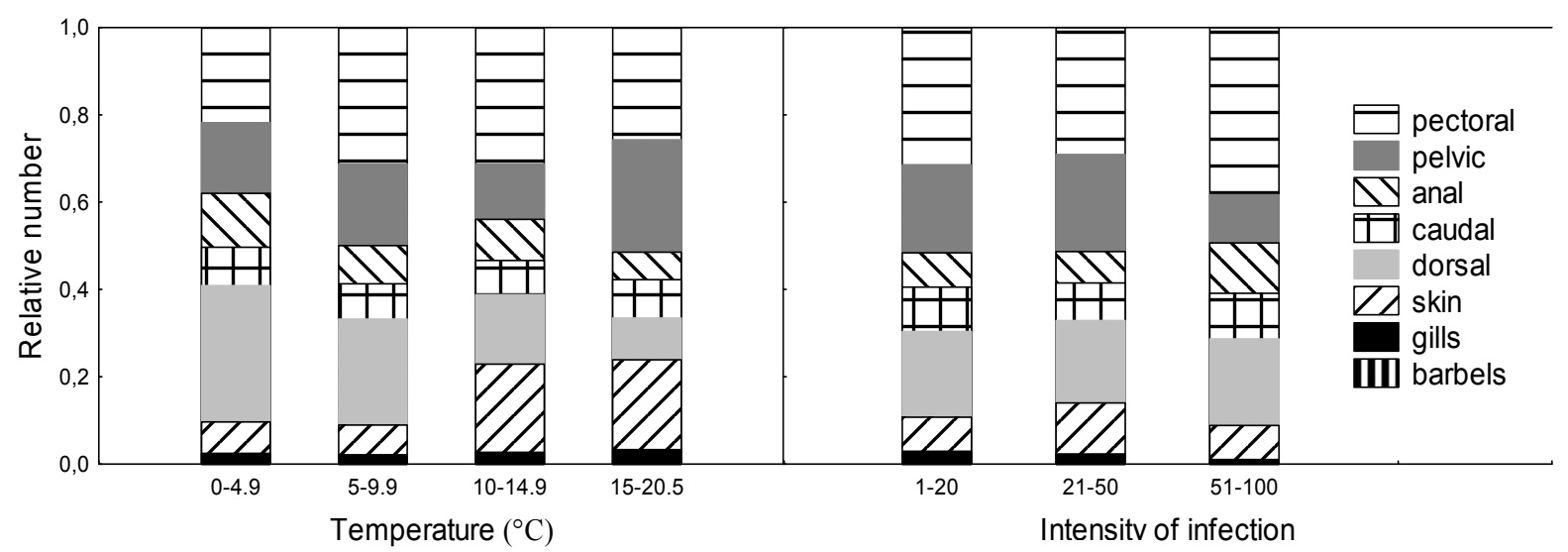

C

Gyrodactylus gobii

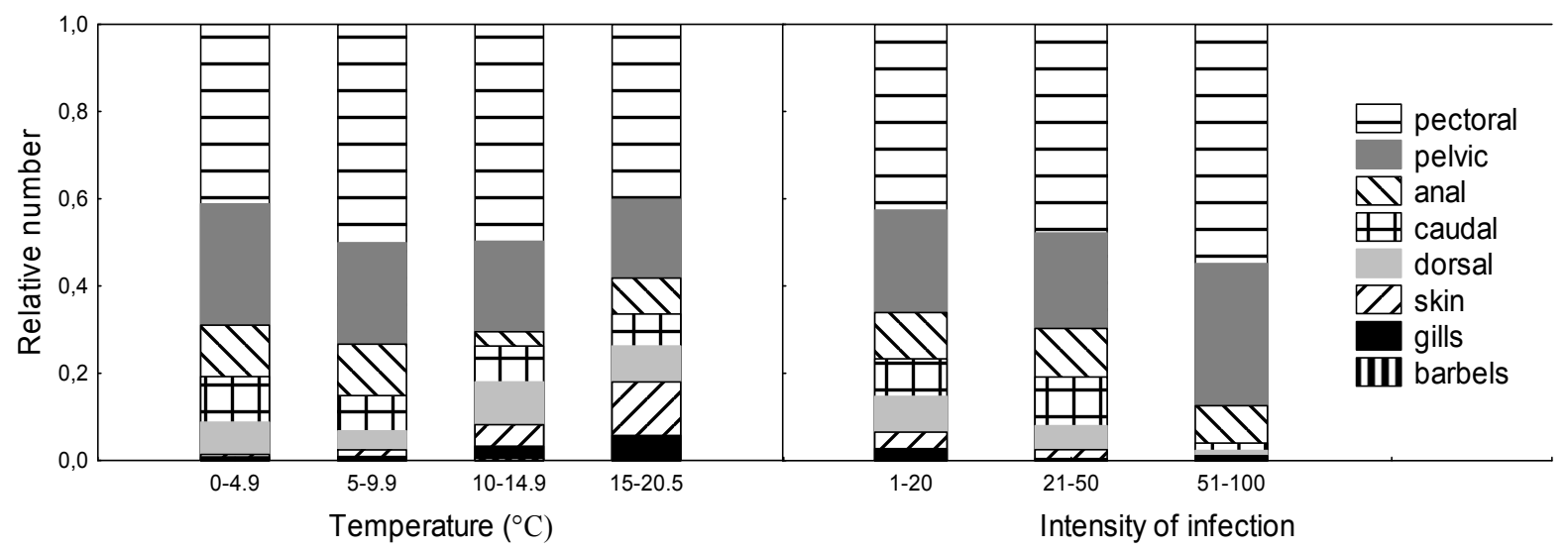

Fig. 5. Distribution of monogenean A) Dactylogyrus cryptomeres, B) Gyrodactylus gobiensis and C) G. gobii on different microhabitats on gudgeon in relation to the water temperature and intensity of infection.

survival of parasites (Scott \& Nokes, 1984; Jansen \& Bakke, 1991; Mo, 1997) and determines the immune response of the host (Aaltonen et al., 1994). Several authors previously described seasonal patterns in occurrence of monogenean parasites (Žitňan \& Hanzelová, 1982; Valtonen et al., 1990; Appleby, 1996; Mo, 1997). In the present study, intensity of infection of all monogenean species correlated with their prevalence, as did abundance and prevalence in the studies of Poulin (1999) and Morand and
Guégan (2000). Gyrodactylids peaked in spring, when the water temperature increased above $6{ }^{\circ} \mathrm{C}$. Dactylogyrus cryptomeres seems to be more thermophilous and in both years peaked later when water temperature increased above $14{ }^{\circ} \mathrm{C}$. Among gyrodactylids, G. markakulensis peaked in August in both studied years and thus it appears to be more thermophilous than the other species of this group. Water temperature optimal for reproduction and survival varies among Gyrodactylus species. For example, Cone and 
Cusack (1988) observed the highest numbers of Gyrodactylus salmonis and Gyrodactylus colemanensis at water temperature below $8{ }^{\circ} \mathrm{C}$, whereas Žitňan and Hanzelová (1982) recorded the optimal temperature for reproduction of $G$. shulmani to be $20^{\circ} \mathrm{C}$. In the present study, gyrodactylid populations started to grow with increasing temperature in spring. With further increase of temperature gyrodactylids decreased, probably due to a combination of shortening life span together with host-induced parasite mortality (Andersen \& Buchmann, 1998). The host response is enhanced in a few weeks at $15{ }^{\circ} \mathrm{C}$ (Aaltonen et al., 1994). In the autumn, the intensity of infection of gyrodactylids increased again, but slowly, due to lower population growth in cold water (Jansen \& Bakke, 1991). Microhabitat of monogenean parasites depends on parasite species, its developmental stage or phase of the parasite population, on host fish species and on the immune response of host. In addition, abiotic factors of the water environment play a significant role (Koskivaara et al., 1991; Buchman \& Uldal, 1997; Buchmann \& Bresciani, 1998). In the present study, D. cryptomeres and P. homoion occurred strictly on the gills. When the highest intensity of $D$. cryptomeres was observed, parasites were attached mainly on the third gill arch, which is the largest one with the strongest respiratory current (Paling, 1968). The majority of gyrodactylid specimens were found on the fins. Gyrodactylus gasterostei and G. vimbi were both observed on the skin in more than $20 \%$ of cases. These species are considered as generalists (Harris et al., 2004) and might not be so specific to microhabitat as reported for specialists such as G. gobiensis and G. gobii. Even with increasing temperature, when conditions for survival of $G$. gobiensis and G. gobii became unsuitable, these species remained on pectoral and pelvic fins, but also occurred on the skin. A different pattern was observed in thermophilous species G. markakulensis: in warm months the fins harboured $94 \%$ of specimens and in cold months when conditions for survival worsened, parasites preferred the gill apparatus (86 \%). Similarly, Koskivaara et al. (1991) found gyrodactylids more frequently on the gills when the environmental conditions were not suitable for parasite survival.

Also with increased intensity of infection, G. gobiensis and G. gobii were attached more often to pectoral and pelvic fins, due to the better possibility of transmission to a new host fish (Cone \& Cusack, 1989). In the study of Jensen and Johnson (1991) G. salaris was more likely to attach to the skin of Salmo salar as intensity increased, because microhabitats on the fins were already occupied. Gudgeon is a fish inhabiting the river bottom, so it was predicted that pectoral and pelvic fins are likely to be the most important sites for gyrodactylid transmission because detached parasites might transfer also via the sediment (Bakke et al., 1992).

Maximal density of Gyrodactylus spp. observed was one specimen per $5 \mathrm{~mm}^{2}$. It seems, therefore, that gyrodactylids of gudgeon under natural conditions usually do not occur in densities leading to death of the host, as observed e.g. by
Bakke et al. (1992) in Gyrodactylus salaris parasitizing $S$. salar. In the present study, most monogeneans were aggregated in a few fish and so much higher standard deviations than means of the intensity of infection were observed (Table 1).

\section{Acknowledgements}

We greatly thank Dr. Miroslav Prokeš for help in collecting fish. We are indebted to Prof. Graham Kearn for English corrections. The present study was supported by the Ministry of Education of the Czech Republic Project No. MSM 0021622416. J.J. was funded by the Ministry of Education of the Czech Republic (Project No. MSM 0021622412 INCHEMBIOL), B.K. and M.G. by the Ichthyoparasitology Research Centre of the Ministry of Education, Youth and Sports of the Czech Republic (LC 522).

\section{References}

Aaltonen, T. M., Jokinen, E. I., VAltonen, E. T. (1994): Antibody-synthesis in roach (Rutilus rutilus) - analysis of antibody-secreting cells in lymphoid organs with ELISPOT-assay. Fish Shellfish Immun., 4: 129 - 140

ANDERSEN, P. S., BuChMANN, K. (1998): Temperature dependent population growth of Gyrodactylus derjavini on rainbow trout, Oncorhynchus mykiss. J. Helminthol., 72: 9 14

APPLEBY, C. (1996): Seasonal occurrence, topographical distribution and transmission of Gyrodactylus callariatis (Monogenea) infecting juvenile Atlantic cod, Gadus morhua, in the Oslo Fjord, Norway. J. Fish Biol., 48: $1266-$ 1274

Bakke, T. A., Harris. P. D., Jansen, P. A., Hansen, L. P. (1992): Host specificity and dispersal strategy in gyrodactylid monogeneans, with particular reference to Gyrodactylus salaris (Platyhelminthes, Monogenea). Dis. Aquat. Organ., 13: 63 - 74

BAKke, T. A., CABle, J., HARris, P. D. (2007): The Biology of Gyrodactylid Monogeneans: The "Russian-Doll Killers". Adv. Parasit., 64: 161 - 376

BARSE, A. M. (1998): Gill parasites of mummichogs, Fundulus heteroclitus (Teleostei: Cyprinodontidae): effect of season, locality, and host sex and size. J. Parasitol., 84: $236-244$

BUCHMANN, K., BRESCIANI, J. (1998): Microenvironment of Gyrodactylus derjavini of rainbow trout Oncorhynchus mykiss: association between mucous cell density in skin and site selection. Parasitol. Res., 60: $17-24$

BuchmanN, K., Uldal, A. (1997): Gyrodactylus derjavini infection in four salmonids: comparative host susceptibility and site selection of parasites. Dis. Aquat. Organ., 28: 201 $-209$

Bush, A. O., Lafferty, K. D., Lotz, J. M., Shostak, A. W. (1997): Parasitology meets ecology on its own terms: Margolis et al. revised. J. Parasitol., 83: $575-583$

Cable, J., Harris, P. D., Tinsley, R. C. (1998): Life history specialization of monogenean flatworms: a review of 
experimental and microscopical studies. Microsc. Res. Techniq., 42: 186 - 199

CONE, D. K., CUSACK, R. (1988): A study of Gyrodactylus colemanensis Mizelle and Kritsky, 1967 and Gyrodactylus salmonis (Yin and Sproston, 1948) (Monogenea) parasitizing captive salmonids in Nova Scotia. Can. J. Zool., 66: $409-415$

CONE, D. K., CusACK, R. (1989): Infrapopulation dispersal of Gyrodactylus colemanensis (Monogenea) on fry of Salmo gairdneri. J. Parasitol., 75: 702 - 706

DorovsKIKH, G. N. (2005): Component communities of the parasites of gudgeon (Gobio gobio L.) from the basins of Northern Dvina and Mezen rivers. Parazitologiya, 39: 221 - 236 (in Russian)

ERGENS, R. (1991): A new species of the genus Gyrodactylus Nordmann, 1832 (Monogenea) from Gobio gobio (L.). Folia Parasit., 38: 83 - 85

GELNAR, M. (1991): Experimental verification of the effect of constant and changing water temperature on the micropopulation growth in Gyrodactylus gobiensis Glaser, 1974 (Monogenea) parasitizing gudgeon (Gobio gobio, L.). Folia Parasit., 38(2): 123 - 131

GusSEV, A. V. (1985): Monogenea. In: BAUER, O. N. (ed) Identification key to parasites of fresh-water fishes. Part 2, Nauka, Leningrad (in Russian)

HARRIS, P. D. (1988): Changes in site specificity of Gyrodactylus turnbulli Harris, 1986 (Monogenea) during infection of individual guppies (Poecilia reticulata Peters, 1859). Can. J. Zool., 66: 2854 - 2857

Harris, P. D., Shin, A. P., CABle, J., BAKKe, T. A. (2004): Nominal species of the genus Gyrodactylus von Nordmann 1832 (Monogenea: Gyrodactylidae), with a list of principal host species. Syst. Parasitol., 59: $1-27$

JANSEN, P. A., BAKKE, T. A. (1991): Temperature-dependent reproduction and survival of Gyrodactylus salaris Malmberg, 1957 (Platyhelminthes: Monogenea) on Atlantic salmon (Salmo salar L.). Parasitology, 102: 105 - 112

Jensen, A. J., Johnsen, B. O. (1991): The site specificity of Gyrodactylus salaris Malmberg, 1957 (Monogenea) on Atlantic salmon (Salmo salar L.) in the River Lakselva, northern Norway. Can. J. Zool., 70: $264-267$

KAmiso, H. N., OLSON, E. (1986): Host-parasite relationship between Gyrodactylus stellatus (Monogenea: Gyrodactylidae) and Parophrys vetulus (Pleuronectidae-English sole) from coastal waters of Oregon. J. Parasitol., 72: 125 $-129$

Koskivaara, M., Valtonen, E. T., Prost, M. (1991): Seasonal occurrence of gyrodactylid monogeneans on the roach (Rutilus rutilus) and variations between four lakes of differing water quality in Finland. Aqua Fenn., 21: 47 - 55 Lindestrøm, T., Buchmann, K. (2000): Acquired resistance in rainbow trout against Gyrodactylus derjavini. J. Helminthol., 74: 155 - 160

MAlmberG, G. (1970): The excretory systems and the marginal hooks as a basis for the systematics of Gyrodactylus (Trematoda, Monogenea). Ark. Zool., 23: 1 - 235

Mo, T. A. (1992): Seasonal variation in the prevalence and infestation intensity of Gyrodactylus salaris Malmberg, 1957 (Monogenea: Gyrodactylidae) on Atlantic salmon parr, Salmo salar L., in the River Batnfjordselva, Norway. J. Fish Biol., 41: 697 - 707

Mo, T. A. (1997): Seasonal occurrence of Gyrodactylus derjavini (Monogenea) on brown trout, Salmo trutta, and Atlantic salmon, S. salar, in the Sandvikselva River, Norway. J. Parasitol., 83(6): 1025 - 1029

MORAND, S., GuÉGAN, J. F. (2000): Distribution and abundance of parasite nematodes: ecological specialisation, phylogenetic constraint or simply epidemiology? Oikos, 88: $563-573$

PALING, J. E. (1968): A method of estimating the relative volumes of water flowing over the different gills of a freshwater fish. J. Exp. Biol., 48: 533 - 544

PeČínKovÁ, M., MatěJusovÁ, I., KoubKovÁ, B., GELNAR, M. (2005): Classification and occurrence of abnormally developed Paradiplozoon homoion (Monogenea, Diplozoidae) parasitizing gudgeon Gobio gobio. Dis. Aquat. Organ., 64: $63-68$

PIELOU, E. C. (1975): Ecological diversity. John Wiley \& Sons, New York

POULIN, R. (1992): Determinants of host-specificity in parasites of freshwater fishes. Int. J. Parasitol., 22: $753-$ 758

POULIN, R. (1999): The intra- and interspecific relationships between abundance and distribution in helminth parasites of birds. J. Anim. Ecol., 68: $719-725$

SCOTT, M. E., NoKES, D. J. (1984): Temperature-dependent reproduction and survival of Gyrodactylus bullatarudis (Monogenea) on guppies (Poecilia reticulata). Parasitology, 89: $221-227$

STATSOFT, INC. (2006): STATISTICA (data analysis software system), version 7.1., http://www.statsoft.com Valtonen, E. T., Prost, M., RAhKonen, R. (1990): Seasonality of two gill monogeneans from two freshwater fish from an oligotrophic lake in northeast Finland. Int. J. Parasitol., 20: 101 - 107

ŽITŇAN, R., HANZELOVÁ, V. (1982): Seasonal dynamics of the invasion cycle of Gyrodactylus shulmani Ling Mo-En, 1962 (Monogenea). Folia Vet., 26: 183 - 194 